INDEPENDENT JOURNAL OF MANAGEMENT \& PRODUCTION (IJM\&P)

http://www.ijmp.jor.br

v. 11, n. 6, September - October 2020

ISSN: 2236-269X

DOI: 10.14807/ijmp.v11i6.1118

\title{
PERFORMANCE PERSISTENCE OF MUTUAL FUNDS: EVIDENCE FROM BANGLADESH
}

Mohammad Abir Shahid Chowdhury School of Economics and Management China University of Geosciences, Wuhan, China

E-mail: 2956529951@qq.com

Zahid Ali

Department of Commerce and Management University of Malakand, Pakistan E-mail: zahidzady@yahoo.com

Muhammad Usman Department of Economics and Business Administration University of Education, Lahore (Faisalabad Campus), Pakistan E-mail:m.usman@ue.edu.pk

Asad Ullah

School of Management Huazhong University of Sciecne and Technology, Wuhan, China E-mail: assad@hust.edu.cn

Submission: 9/5/2019

Revision: 11/9/2019

Accept: 11/22/2019

\section{ABSTRACT}

Purpose: Since 1990s, the discussion on whether mutual funds can perform better and persistently as compare to market has become an ongoing issue. Current research investigates the performance persistence of equity mutual funds', particularly in the financial market of Bangladesh.

Theoretical Framework: Different researchers have strived to examine the performance of mutual funds by using numerous performance indicators and risk adjustment techniques.

Design/Methodology/Approach: The equity mutual funds data for this study are obtained from DSE (Dhaka Stock Exchange) database. The sample set includes all open-end mutual funds from 2010 to 2015. There is no mutual fund that has ceased trade or merged with other mutual funds during the study period. 
Originality/Value: Broad literature have been directed on the performance and persistence of mutual funds in the American markets, while some of the studies also centered on Australia, China, Hong Kong and U.K. financial markets. However, in the context of Bangladesh's financial market, no identical research has been carried on the performance persistence of mutual funds.

Findings: The results reveal that the managers of equity mutual funds have selective ability to obtain higher returns in Bangladesh. Moreover, the past performance of mutual funds has an impact on their future performance. The size of mutual funds doesn't have any impact on their performance. The parametric and non-parametric models demonstrate that as compare to long run, equity mutual funds in Bangladesh could perform persistently in the short-run.

Keywords: Mutual Funds; Fund Size; Past Performance; Selective Ability; Performance Persistence

\section{INTRODUCTION}

The mutual fund market has crossed an outstanding advancement during the past two decades. Individuals now prefer mutual funds as an investment vehicle. They provide skilled administration and various portfolio even for low capital shareholders that bring tremendous success. In a domain of perfect competition and symmetric observation, it is considered as a Pareto efficient in terms of welfare point of view to invest on actively organized portfolio.

Since last few decades, mutual funds have been considered as the investor's tool of preference for long-term financing. A mutual fund attracts the money of investors who has similar financial objectives. Mutual fund is one of the main chosen investment substitutes for the risk averts shareholders as it provides opportunities to finance in a diversified, skillfully managed portfolio at low costs.

Previous studies on developing markets' fund performance showed positive sign of short-term abnormal returns (HUJJ; POST, 2011). As present evidence suggest such abnormal returns are occurred mainly by high economic growth rates of their native economies and insufficient required knowledge about native investment atmosphere on the place of trendy foreign fund managers and individual investors but not by superior selection or ability of timing of local fund managers.

However, on the other hand such studies also give an evidence that with sequence of exchanging booming and narrowing market situations, the performance of emerging economies 
DOI: 10.14807/ijmp.v11i6.1118

mutual funds is developing, as local fund managers are achieving more skill and trend of the market (HOEPNER; HUSSAIN; REZEC , 2011).

The major obstacles for developing markets fund industries expansion and out performance lies in limited possibilities for short selling, immature markets for derivatives, unskilled management, establishing headquarters away from financial centers and, thus, limited opportunities for knowledge spillovers, high degree of country regulations and supervision (ELINGA; FAUSTB, 2010).

As for overall market studies, so there are mainly research with emphasis on Latin American, Asia- Pacific, Indian, South African and Islamic fund industries, providing a positive proof of local fund returns that are pretty high to cover fund costs (DELCOURE; FRENCH, 2007)

Mutual funds market in Bangladesh is very small. At present, 40 mutual funds are available in the markets. Till now, 40 mutual funds altogether make less than $5 \%$ of our total market capitalization with joint assets of more than Tk. 220 million (1USD=78TK). However, this tiny market is not perfect enough at this moment. In this circumstance, monitoring of mutual funds has become crucial. It becomes significant to research on the performance persistence of mutual fund industry.

The relation between risk-return decides the performance and the return trend shows the persistence of a mutual fund scheme. Thus, the purpose of the study objective of this thesis is to analyze the performance of growth oriented mutual funds and along with that to present a wide analysis about the factors which directly or indirectly influence the price and the complete performance of the mutual funds as a whole. The considerations beneath the performance evaluation of mutual funds are a matter of subject to the investors, fund managers and researchers alike.

The paper is organized in sections: section 2 discusses the theoretical background of the study, section 3 reviews the literature, section 4 discusses the research hypothesis, section 5 explains the methodology and details the sample of the study, data sources, variables selection and measurement, as well as the empirical results are reported in this section. Lastly, section 6 concludes the findings and suggests policy implications.

\section{THEORETICAL BACKGROUND}

The most widely used model in researches on mutual fund performance is a "CAPM single index" model. Modern studies on the cross-sectional disparity of stock returns e.g., Fama 
DOI: 10.14807/ijmp.v11i6.1118

and French (1993), raised the question about acceptability of a single index model to explain mutual funds' performance. Fama and French (1993) three-factor model is chosen to provide better clarification of stock behavior. Furthermore, as a value weighted market indicator, this model holds two additional risk factors i.e., fund size (SMB) and book to market (HML). Although, this model already amends ordinary CAPM pricing errors, it is not capable for momentum-sorted portfolio returns to clarify the cross-sectional variation.

Therefore, Carhart (1997) prolongs the Fama French model with the extension of a fourth $\left(4^{\text {th }}\right)$ factor which explains the momentum anomaly (PR1YR). Such modified model is reliable with market equilibrium model along with four risk factors, which can also be called as a performance attribution model. The fraction of the average yield attributable to four fundamental strategies can be specified by the coefficients and premia on the factor-mimicking portfolios. Since then, this has turned to the standard model to evaluate mutual fund performance.

\section{LITERATURE REVIEW}

Persistence research started with Fonte bibliográfica inválida especificada. that aided to value mutual fund performance with respect to the reward-to-volatility ratio known as Sharpe ratio between 1944 and 1953 and the period 1954 to 1963 . The author placed order mutual funds using Sharpe ratio and discovered a correlation between the two periods of 0.36 with a t-ratio of 1.88. Sharpe (1966) also marked mutual fund performance in terms of the (TREYNOR,1966) ratio for the same two periods.

The riskiness of a fund in Sharpe ratio, which measured its own risk, was replaced by the total volatility. The correlation between the two periods based on the (TREYNOR, 1966) ratio is 0.4008 with a t-ratio of 2.47 . The comparison in mutual fund performance in the simultaneous period can be assumed by both methods. The author stated the phenomenon of mutual fund performance persistence might exist.

Majority of the research regarding performance evaluation is related to UK and US markets. In the earlier research studies ethical funds were compared to wide market indices such as FT all share index. Employing the same methodology, Luther et al., (1992) analyzed 15 ethical unit trusts returns. They concluded that ethical funds have the capability to beat general market indices.

Blake and Timmermann (1998) explained mutual fund performance persistence in the U.K. The data consists of 2375 mutual funds for monthly returns from 1972 to 1995 . The writer 
DOI: 10.14807/ijmp.v11i6.1118

found that U.K. mutual funds have an average of 1.8\% annual underperformance on a riskadjusted basis. The authors also mention(HENDRICKS; PATEL; ZECKHAUSER, 1993) formula to classify the monthly mutual funds in the sample into quartiles according to abnormal performance over the previous 24 months.

Quartiles are further divided into equal-weighted portfolios held for one month; the highest performers are in the top portfolio (quartile) and the lowest performers are in bottom portfolio (quartile). The results showed all top portfolios mean positive abnormal yields over the assessment time and all bottom portfolios have average negative irregular yields. The outcomes were correlated with (ELTON; GRUBER; BLAKE,1996) results that indicated mutual fund performance in the U.S. is persistent; although the performance of mutual funds, on average, underperforms relative to the passive indices.

Allen and Tan (1999) examined U.K. mutual fund performance persistence with a dataset of weekly returns of 131 funds from 1989 to 1995. The U.K. fund managers return index was served as the benchmark. The study used (GOETZMANN; IBBOTSON'S, 1994) two way contingency tables to check persistence in the long-term (more than one year or two year intervals).

Winners and losers were mentioned based on their last performance. The output mention $56 \%$ of the funds repeat their above average performance calculated by raw returns, and $59 \%$ of winners subsequently perform well when performance is calculated by riskadjusted returns. In the short-term (semiannually or monthly), however, the evidence emerge with reverse.

Furthermore, three empirical tests, OLS regression of risk-adjusted excess yields and independent-SRCC (Spearman's rank correlation coefficient) measurements, all give little evidence to confirm the (FLETCHER; FORBES, 2002) investigated the persistence in U.K. unit trust (open-end mutual funds) performance from 1982 to 1996. The dataset consisted of monthly returns of 724 trusts and all selected trusts were equity funds. The financial times all shares (FTA) index was taken as the benchmark. The authors used (JENSEN, 1968; CARHART, 1997; CONNOR; KORAJCZYK, 1991) methodology to calculate trust performance.

The authors also used (BROWN; GOETZMANN'S, 1995) method to make two-way contingency tables and measured the log-odds ratio to test for persistence. Their outcomes showed significant performance persistence of trusts when performance was calculated by 
DOI: 10.14807/ijmp.v11i6.1118

Capital Asset Pricing Model (CAPM) or Arbitrage Pricing Model (APT). Persistence was absent when performance is evaluated by the (CARHART, 1997) method. The authors contradicted that performance persistence of U.K. trusts was not because of superior stock selection ability, but can be illustrated by factors that were useful to capture cross-sectional differences in stock returns.

Cuthbertson, Nitzsche AND O'Sullivan (2008) examined the performance of U.K. equity unit trusts and open-end investment firms from 1975 to 2002. The statistics consisted of monthly returns of 935 funds and the financial times all Shares (FTA) index. All funds in the sample were marked into quintiles based on historical performance (alphas) that are originated from the (CARHART, 1997) four factor model.

The quintiles were recalculated in length of $1,3,6,9$, and 12 months and the returns of quintiles are compared. The output showed past-winner funds do not continuously give better performance. On the contrary, past-losers remain losers and negative $2 \%$ abnormal return annually was explored from the bottom quintile. The authors dispute that the fact of mutual fund performance persistence might be backed by low performing mutual funds.

Bollen and Busse (2005) followed the Carhart, (1997) four-factor model and modify (TREYNOR; MAZUY, 1966; HENRIKSSON; MERTON, 1981) market timing models consisted of three additional descriptive variables (BTM, HML, and MOM), for the dataset of 230 mutual funds to calculate the alphas (risk-adjusted returns) from 1985 to 1995 on everyday basis in the U.S. market.

All funds of four subsequent months in the sample were marked by risk-adjusted returns into sample and then an assumption of the each observation performance was achieved in the consecutive periods. The mean excess returns of the upper docile is 39 basis points per quarter in the post ranking four subsequent months and the bottom docile produces minus 77 basis points excess returns per quarter.

The outcome noted that the underperforming mutual funds could continuously produce unfavorable results and the successful mutual funds could persistently give positive excess returns. The researcher then changed the assessment period from one quarter to one year. In the post-ranking quarter the four subsequent months mean excess returns of the top decile reduce to 9 basis points, and the statistically unimportant outcome recommends. 
DOI: 10.14807/ijmp.v11i6.1118

We can also find similar outputs for mutual funds which were mentioned by raw-returns rather than risk adjusted returns. The study suggested that high performance was found in short term only due to information advantage some managers.

Christensen (2005) research assured the outcome with (FLECTCHER, 1999) and (DAHLQUIST; ENGSTROM; SODERLIND, 2000) findings which commended insignificant evidence of performance persistence of equity mutual funds in Denmark during 1996-2003. Mutual fund performance was employed on the basis of the single-index alpha (JENSEN, 1968).

Mutual funds in the sample were then marked in a two-way contingency table (GOETZMANN; IBBOTSON, 1994) to check for performance persistence. The overall investigation period is divided into three two and half-year length. According to Christensen (2005), a flow of performance persistence is observed but the outcomes are statistically insignificant.

Rhodes (2000) argued if funds riskiness changes rapidly over time, market efficiency might predict persistence in raw return. A current task by (CLIFFORD et al., 2011) rejects the benefit of having risk adjusted returns from the investors' perspective. They assured the performance flow relationship and described that investors follow past performance without considering risk. If return is degenerated from both raw returns and the standard deviation of the return, the risk measure, the coefficient on standard deviation is not mathematically significant.

Given that risk is irrelevant to average mutual fund investors, they explained the reason that managers are unable to consistently produce positive risk adjusted returns to get the manager's incentive, not the lack of skills. Although sometimes high raw return stock is value destroying, managers like to choose it. Another stipulating paper by (FRIESEN; SAPP, 2007) worked to disclose fund investors' timing ability. To reveal investors' timing ability they considered the difference between time weighted return and dollar weighted return.

Time weighed return serves a measure of the performance of the funds. While dollar weighed return is the internal rate of return of currency under administration, which is assumed to be a measure of the investors' performance. Wermer (2000) said that turnover is not related to fund returns and (JEGADEESH; CHEN; WERMERS, 2000) found that income is positively related with fund yields. According to (SOUZA, 2015) funds with high raw return do worse in the future than funds with low raw return. 
This is because the stocks sold by high raw return funds have their prices pushed up and subsequently underperform. He argues that funds with low raw return sufferer "unsophisticated" outflows, forcing them to make un-optimal sales of stocks whose prices then quickly change. According to (ALEXANDER; CICI; GIBSON, 2007) such transaction were less likely to contain information, but may, in total, changed share price.

As a result stocks having positive flow funds have increased their conditions will likely have upturn in price without information and so would be habituated to underperform. As performance is chased by return, these stocks are likely to be the ones held by well-performing funds, and the switch will result in these funds underperforming. On the contrary, stocks sold by funds with outflows should outperform in the future, improving the performance of funds that have done badly in current period.

Bessler, Drobetz and Zimmermann (2009) inspected German mutual equity funds performance from 1994 to 2003. The sample included monthly returns of 50 equity funds. The DAX blue-chip index, MSCI Germany total return index and DAFOX are the yardstick indices. The Jensen alpha is negative 55 basis points per year, on average, for the total sample of funds, and the average abnormal return is even worse, a negative result of 260 basis points per year employing the (FAMA; FRENCH , 1993) three-factor model. Ferson and Schadt (1996) put the stochastic discount factor (SDF) framework, which is similar to (FARNSWORTH et al., 2002). German mutual funds cannot have excess returns compared to the benchmark on average according to researchers’ comments.

Using risk return relationship model and variables for 16 mutual funds in Bangladesh Salim et al. (2010) examined performance equity based mutual fund. The result explored that different variables provide different results which is inconsistent due to time period. Deepak (2009) focused on the analytical examination based on fund manager performance and interpreting data according fund manager and fund investor levels.

\section{HYPOTHESIS DEVELOPMENT}

This part explains the research hypotheses used in this study.

\subsection{Fund size and performance}

The size of mutual fund has become one of the widely used factors in mutual fund research for long time, and the connection between performance and fund size still bemuse researchers and academics. Some research try to solve questions like does fund size affect 
DOI: 10.14807/ijmp.v11i6.1118

performance? Does performance vary in small scheme than in large scheme? Does small fund give more stable performance?

Big fund size provides several benefits than small ones. Firstly, large funds can get advantage from economies of scale. Larger funds can split fixed costs over a larger asset base, and have more resource or ways to research. Manager of big funds have advantage on investment opportunities that are not available to small market participants (CICCOTELLO; GRANT, 1996). According to ( BERK; GREEN, 2004), explains the economies of scale may higher the ability of large funds to outperform their passive benchmarks.

However, large funds have some difficulties and administration issues and the ranking ability of investments is determinants/ principle of fund performance persistence performance (GRUBER, 1996) and (BERK; GREEN, 2004)). When small funds can focus their money on a few investment opportunities, but when it becomes big funds must concentrate on safe and profitable investment opportunities and managerial skills effect becomes scattered (Diseconomies of scale).

Some researchers obtain a negative association between performance and fund size. Indro, et al. (1999) argued that marginal returns become lower as funds become larger and so they suffer diseconomies of scale. They show that funds do not capture the additional returns that suffer an over investments in research due to their diseconomies of scale.

Chen, Hong, Huangand Kubik (2004) showed that fund returns decrease with lagged fund size. According to (DAHLQUIST; ENGSTROM; SÖDERLIND, 2000) smaller equity funds tend to perform better than smaller equity funds in Sweden. This study supports the view of relationship between fund size and performance and hypothesized that

- $\mathrm{H}_{1}$ : There is no significant relationship between mutual funds size and performance.

\subsection{Fund return and fund performance}

Schwager (2012) described Past returns are not future returns. If there were no reasons to rely on those future market scenarios that are not likely to be tremendously same from those which show past returns, past returns can be very misleading. Mauboussin (2010) argued that although there is a small percentage of investors who have sufficient skills to offset taxes, it is practical to conclude that there is deficit of evidence of ability to invest. Therefore, investing mainly is more a matter of luck than skill in short periods of time. 
DOI: 10.14807/ijmp.v11i6.1118

However, anyone who is interested into examining performance, data provides a true sense for how those returns were produced. This includes not only understanding the data itself but also some function related to the risks and method applied for the sustainability. This is no small issue, it requires an ability to apprehend investment strategies and how they behave in different market conditions. Above all the performance data we see and so often possess about, it also requires a measure of modesty and appreciation that luck plays an important role. Therefore, our next hypothesis is

- $\mathrm{H}_{2}$ : Future fund performance can be predicted by past performance.

\subsection{Fund managers' selection ability and fund performance}

The selection ability of fund managers and book to market and firm size relationship seems to be asymmetric as selection of top performers are more sensitive to their performance than selection to poorly performing funds. The sensitivity of flows to performance decreases with time and funds size and book to market become important factor for managers in terms of selection ability.

Fama and French (1993) argued that the effects of book to market and firm size enlisted companies give explanatory power and the beta in CAPM is not enough to explain stock returns. The momentum effect should also be considered by mutual fund managers as it is one of the mostly academically investigated effects with strong persistence.

In order to test hypothesis three, we choose the (CARHART, 1997) model, which is based on the Fama and French model also consider returns generated by the momentum effect which was explained in (JEGADEESH; TITMAN, 1993). This technique was used in buying and selling shares with respect to high and low past year's yields. All these variables in Carhart model explain the relationship between each variable and mutual fund performance. Therefore, our third hypothesis is stated as

- $\mathrm{H}_{3}$ : Book-to-market ratio, firm size in stock market and momentum effect has combined influence on mutual fund managers' selection ability.

\subsection{Fund return and short-run persistence}

According to Hendricks, Patel and Zeckhauser (1993), growth oriented mutual funds in terms of short term relative performance have strong support for persistence in one year assessment horizon. However, (MALKIEL, 1995) indicates that only the more successful mutual funds exist. After management expense and even gross of expense funds have 
DOI: 10.14807/ijmp.v11i6.1118

underperformed benchmark portfolios when allowance is given for survivorship bias in total. Further he mentioned that plenty of performance persistence found in prior period; there was no consistency in scheme returns in future period.

We test the flow of persistence of stock manager performance. We want to assume whether a fund manager who has done well in one period can do this performance in subsequent periods in short run. Both non-parametric and parametric method is used to test mutual fund performance persistence. Goetzmann and Ibbotson (1994) introduced non parametric method using two-way contingency table to examine mutual fund performance persistence. The parametric method used a regression model to test mutual fund performance persistence (GRINBLATT; TITMAN, 1989; BROWN et al., 1992).

Mutual fund performance is analyzed by raw returns (net returns), the single-index alpha and the four-index alpha (CARHART, 1997) by using (GOETZMANN; IBBOTSON, 1994) non-parametric tests. Pairs of mutual fund performances in previous and subsequent years are used to form Two-way contingency tables. Then two-way contingency tables are used to calculate The Cross Product ratio (CPR).

If the value of CPR is equal to one, mutual funds do not perform persistently. It indicates mutual funds could perform persistently, if the CPR is greater than one. A Z-test shows statistical significance for each one-year interval for the entire study period. On the contrary, the parametric method are calculated by using both the (JENSEN, 1968) risk-adjusted returns and (CARHART, 1997) risk-adjusted returns. Previous risk-adjusted return is used to regress the current risk-adjusted return. A positive coefficient of previous risk-adjusted return indicates that the mutual fund performance could be forecast based on its previous performance. In other words, the mutual fund might perform persistently. So according to above explanation this hypothesis is

- $\mathrm{H}_{4}$ : Equity mutual funds in Bangladesh could not perform persistently in the short run.

\subsection{Fund return and long-run persistence}

Most previous researchers apply a two or three-year interval to test performance persistence in the long run (GOETZMANN; IBBOTSON, 1994; PHELPS; DETZEL, 1997). Since the Bangladesh mutual fund industry has a short history and the first equity funds in the data sample in this study was established in 2000, there is a shortage of data of mutual funds 
DOI: 10.14807/ijmp.v11i6.1118

for a three-year interval test. Therefore, the two-year interval is the appropriate size of research period for mutual funds in Bangladesh.

The process of the testing the hypothesis is identical to the methods used to test the Hypotheses of short term persistence. Here also both non-parametric and parametric methods are employed and mutual fund performance is measured in terms of raw returns (net returns), single index alpha (JENSEN, 1968) and four-index alpha (CARHART, 1997). The only dissimilarities is that the study period is two-year interval. Blake, Lehmann and Timmermann (n.d.) had chosen pension fund on basis of sample under the same scheme manager to examine the persistency.

Although they figure out the evidence of persistence in scheme returns for fund portfolio at one year range, they contend that the persistence outcome are intertwine with an inverse relationship between fund size and fund performance. We examine the consistency or persistence of fund manager performance. We want to assume whether a fund manager who has performed well in one period can repeat this performance after interval in next periods in long run. If statistical evidence shows that winners in previous period remain same in next period after two years interval then the null hypothesis of no persistence in long run will be rejected. So our last hypothesis is

- $\mathrm{H}_{5}$ : Equity mutual funds in Bangladesh could not perform persistently in the long run.

\section{DATA AND METHODOLOGICAL ESTIMATION}

\subsection{Sample and Data:}

This study has used data of open ended equity mutual funds at DSE (Dhaka Stock Exchange) for the period 2010 to 2015. The study has used data from 2010 because Bangladesh mutual fuds market have observed huge growth in terms of mutual funds in 2010.

The Net Asset Value (already adjusted for dividends), its monthly closing price, no of outstanding shares, market capitalization of mutual funds and Dhaka market index data was collected from DSE library. Risk free rate data was collected from Bangladesh bank.

Table 1: Variable definitions:

\begin{tabular}{lccl}
\hline Variable & Proxy & Expected Sign & \multicolumn{1}{c}{ Definition } \\
\hline Fund return & Monthly fund return & & Return on fund \\
Risk free rate & T-Bill rate & $+/-$ & $\begin{array}{l}\text { Last 3- month risk free rate in month } \\
\text { Market benchmark }\end{array}$ \\
Mkt index & $+/-$ & $\begin{array}{l}\text { Monthly Index return } \\
\text { Return difference between small and }\end{array}$ \\
Value factor & HML & & $\begin{array}{l}\text { large cap portfolio } \\
\text { Return difference between high and low } \\
\end{array}$ \\
& & $+/-$ & book-to- market funds
\end{tabular}


DOI: 10.14807/ijmp.v11i6.1118

Return difference between last year winners and losers

\subsection{Model:}

This article will follow Carhart (1997) which prolongs the Fama-French model with the extension of fourth factor (momentum factor) what was termed as anomaly by Jegadeesh and Titman (1993). The modified model is reliable with a market equilibrium model along with four risk factors, which can also be called as a performance attribution model

Performance of the funds were estimated as follow:

$$
R_{i t}-R_{f t}=\alpha_{i}+\beta_{0}(\mathrm{Rmt}-\mathrm{Rft})+\beta_{1 i} S M B_{t}+\beta_{2 i} H M L_{t}+\beta_{3 i} P R 12_{m t}+\varepsilon_{i t} \ldots \text { (i) }
$$

Excess market return for the study was calculated as the difference between all stocks index return at Dhaka Stock Exchange and Bangladesh Bank risk free rate (proxied by 3-month Treasury bill rate). For SMB, all the funds were ranked based on the market capitalization, and then the bottom $20 \%$ funds of total market were treated as small funds while the top $20 \%$ were treated as big funds. SMB (Fund Size) is the return difference between small and large portfolio.

For HML all the funds were ranked based on their book-to-market ratio. The top 30\% funds were treated as high growth funds while bottom $30 \%$ to the low book-to-market portfolio. HML is then calculated as the difference between return of the high and low growth funds. The momentum factor portfolio PR12m is calculated by posting all stocks on their prior 12-month return. Then PR12m was calculated as the difference of return of top $30 \%$ and bottom $30 \%$ based on last 12 months return.

\subsection{Non-parametric Persistence Test Model}

Mutual fund performance for each year is measured in in terms of returns. By following Goetzmann and Ibbotson (1994) this study termed funds as winners whose return is more than annual median return. On the contrary, funds with performance lower than median are termed as losers. Two types of non-parametric analysis were made for the article, one-year and two years non-parametric tests.

Only funds with the two consecutive years were considered for the single year nonparametric tests. Two-way contingency tables of Goetzmann and Ibbotson (1994), are used to check the persistence in different intervals. Four categories are considered in the two-way contingency tables: winners/winners (WW), winners/losers (WL), losers/winners (LW) and losers/losers (LL). For instance, WW represents the number of two successive periods winners 
DOI: 10.14807/ijmp.v11i6.1118

for one year non-parametric test.

Following Goetzmann and Ibbotson (1994) cross-product ratio (CPR), also termed as odds ratio see Brown and Goetzmann (1995) was calculated. The CPR is measured as (WW $\times \mathrm{LL}) /(\mathrm{LW} \times \mathrm{WL})$, the ratio of the product of repeat performers; repeat winners (WW) and repeat losers (LL) divided by the product of reversal performers; winner-losers (WL) and loserwinners (LW). CPR equal to one or less represents no persistence, while CPR $>1$ proposes persistence. The arithmetical impact of the CPR can be determined by a Z-statistic given by Z= $\ln (\mathrm{CPR}) / \mathrm{SE} \ln (\mathrm{CPR})$.

In addition to this Chi-square statistic, which is well specified, powerful, and more robust to the presence of survivorship bias when compared to other tests of performance (CARPENTER; LYNCH, 1999) given by:

$$
C h i=\frac{(\mathrm{WW}-\mathrm{D} 1)^{2}}{D 1}+\frac{(\mathrm{WL}-\mathrm{D} 2)^{2}}{D 2}+\frac{(\mathrm{LW}-\mathrm{D} 3)^{2}}{D 3}+\frac{(\mathrm{LL}-\mathrm{D} 4)^{2}}{D 4} \ldots
$$

Where D1 $=\{(\mathrm{WW}+\mathrm{WL}) \times(\mathrm{WW}+\mathrm{LW})\} / \mathrm{N}, \mathrm{D} 2=\{(\mathrm{WW}+\mathrm{WL}) \times(\mathrm{WL}+\mathrm{LL})\} / \mathrm{N}, \mathrm{D} 3$ $=\{(\mathrm{LW}+\mathrm{LL}) \times(\mathrm{WW}+\mathrm{LW})\} / \mathrm{N}, \mathrm{D} 4=\{(\mathrm{LW}+\mathrm{LL}) \times(\mathrm{WL}+\mathrm{LL})\} / \mathrm{N}$

Furthermore for robustness we have used Goetzmann and Ibbotson (1994) parametric test, given by $R_{b i}=\alpha_{1}+\alpha_{2} R_{a i}+€_{t}$

Where $R_{a i}$ is the risk-adjusted return of the fund $\mathrm{i}$ (single-index alpha or four-index alpha) from the previous interval and $\mathrm{R}_{\mathrm{bi}}$ is return of the current period.

\subsection{Results and Interpretation}

Table 2 explains descriptive statistics of the variables for the sample size in this paper. In this table we can see difference in number of observation. Here, all independent variables observation number is same except PR12mt as it is calculated based on prior period return. Again, we see that the observation number of dependent variable is less than the number of dependent variable due to unavailability of data.

The average of Rmt - Rft is -0.0679096 where minimum number of $\mathrm{Rmt}-\mathrm{Rft}$ is 0.2664 and maximum number is 0.0652074 , along with standard deviation of 0.0710918 . This table provides the mean of SMBt is 0.0047336 , where minimum is -0.1794 and maximum is 0.8485888. Although it is quite low average for SMBt and PR12mt, funds' performance has weak relationship with market capitalization. 
DOI: 10.14807/ijmp.v11i6.1118

The only independent variable HMLt shows close relationship between mean and standard deviation. Because this variable reflects the effect of funds past return on mutual fund performance that provide better information to shareholders to take decision.

Table 2: Descriptive Statistics

\begin{tabular}{lccccc}
\hline Variable & Observation & Mean & Std. Dev & Min & Max \\
\hline $\mathrm{Ri}-\mathrm{Rf}$ & 2801 & 0.156212 & 1.728585 & -1.023 & 58.00825 \\
$\mathrm{Rm}-\mathrm{Rf}$ & 2952 & -0.0679096 & 0.0710918 & -0.2664 & 0.0652074 \\
$\mathrm{SMB}$ & 2952 & 0.0047336 & 0.1249714 & -0.1794 & 0.8485888 \\
$\mathrm{HML}$ & 2952 & 0.0008038 & 0.0843626 & -0.4611 & 0.2238612 \\
$\mathrm{PR} 12 \mathrm{~m}$ & 2911 & 12.61366 & 105.5469 & -0.6504 & 895.53 \\
\hline \multicolumn{7}{r}{ Source: Author's calculation }
\end{tabular}

Table 3 show the findings of VIF test for tolerance level. The result shows both Bookto market (HML) and Size of fund (SMB) are in tolerance level because both are in less than 5.00 according to rule of thumb. Overall results did not show any sign of multi-collinearity among variables.

Table 3: Variance inflation factors table

\begin{tabular}{lcc}
\hline Variable & VIF & 1/VIF \\
\hline Rm - Rf & 1.06 & 0.946347 \\
SMB & 4.73 & 0.211532 \\
HML & 4.77 & 0.209489 \\
PR12m & 1.04 & 0.957475 \\
Mean VIF & $\mathbf{2 . 9}$ & \\
\hline \multicolumn{3}{c}{ Source: Author's calculation }
\end{tabular}

Table 4 represents all factors of Carhart four-factor model. The four-index alpha value is 0.04964, implies that Bangladeshi mutual fund can earn monthly 4\% excess return on an average after considering compensating for the risk factors incorporated in the above model. The coefficients of book-to-market (HML) and (PR12m) are negative and significant at 1\% level.

Table 4: Regression

\begin{tabular}{|c|c|c|}
\hline \multicolumn{3}{|c|}{ Dependent Variable: $\mathbf{R i}-\mathbf{R}_{\mathbf{f}}$} \\
\hline Variable & Expected Sign & \\
\hline $\mathrm{Rm}-\mathrm{Rf}$ & $+/-$ & $\begin{array}{c}0.4434129 * * * \\
(21.33)\end{array}$ \\
\hline SMB & $+/-$ & $\begin{array}{c}-0.120055 \\
(-0.59)\end{array}$ \\
\hline HML & $+/-$ & $\begin{array}{c}-0.43276^{* * * *} \\
(-3.63)\end{array}$ \\
\hline PR12m & $+/-$ & $\begin{array}{c}-0.00019 * * * \\
(-4.75)\end{array}$ \\
\hline Constant & & $\begin{array}{c}0.04964 \\
(1.66)\end{array}$ \\
\hline No. of Observation & & 2769 \\
\hline $\mathrm{F}(4,40)$ & & $114.96 * * *$ \\
\hline R-Squared & & 0.0006 \\
\hline
\end{tabular}


Table 4 depicts that fund size and fund risk adjusted excess return has negative coefficients but we failed to get significant relationship between firm size and performance in case of Bangladesh mutual funds which doesn't support idea of investing in large cap portfolio. Our result for the fund size is in line with the studies of Ciccotello and Grant (1996), Gallagher and Martin (2005) and Heaney (2008). These studies also reported that funds' performance is not influenced by their size. Furthermore, HML is negatively significant that also supporting the same pattern of investment such as investment in small cap portfolio. In short we found evidences in support of hypothesis 2 and hypothesis.

Table 5: Non-parametric test for short-run Performance Persistence

\begin{tabular}{|c|c|c|c|c|c|c|c|c|c|}
\hline & \multicolumn{5}{|c|}{ No of observations } & \multicolumn{2}{|l|}{ Percentage } & \multicolumn{2}{|l|}{$\mathrm{B} \& \mathrm{G}$} \\
\hline Variable & Funds & $\mathrm{W}-\mathrm{W}$ & W-L & L-W & $\begin{array}{l}\mathrm{L}-\mathrm{L} \\
\end{array}$ & Repeat W & CPR & Z-Test & $\mathrm{Chi}^{2}$ \\
\hline $2011-12$ & 40 & 10 & 4 & 7 & 19 & 25 & 6.7857143 & 2.5925967 & 12.6 \\
\hline 2012-13 & 40 & 6 & 11 & 13 & 10 & 15 & 0.4195804 & -1.317575 & 2.6 \\
\hline 2013-14 & 39 & 11 & 7 & 8 & 13 & 27.5 & 2.5535714 & 1.4202983 & 2.3 \\
\hline 2014-15 & 39 & 11 & 8 & 8 & 12 & 27.5 & 2.0625 & 1.1114318 & 1.3 \\
\hline Total & 158 & 38 & 30 & 36 & 54 & 23.75 & 1.9 & 1.9719463 & 7.9 \\
\hline
\end{tabular}

Table 5 exhibit the number of repeat players and reversal players in every year interim for 2011 to 2015. We ranked the mutual funds as winner or loser in accordance with the funds return's deviation from annual median return. We found that repeat performers are more than reversal players for most of the sample periods. Also, CPR $>1$ is observed for the periods except for 2012-13 where CPR is 0.4195804 . The above table reveals that $58.23 \%$ of the funds give performance persistence. The calculated Z-value for every one-year interim and for the total sample is significant against the critical Z-value of 1.96 .

Table 6: Non-parametric Test of Long Run Performance Persistence

\begin{tabular}{|c|c|c|c|c|c|c|c|c|c|c|}
\hline & & No & obse & tions & & Percentage & Malkiel & & $\& G$ & \\
\hline Variable & Funds & $\begin{array}{l}\text { W- } \\
W\end{array}$ & $\begin{array}{l}\text { W- } \\
\text { L }\end{array}$ & $\begin{array}{l}\text { L- } \\
\text { W }\end{array}$ & L-L & Repeat W & Z-Test & CPR & Z-Test & $\mathrm{Chi}^{2}$ \\
\hline 2011-13 & 40 & 4 & 10 & 15 & 11 & 10 & -1.603567451 & 0.293333 & -1.721463 & 6.2 \\
\hline 2012-14 & 40 & 9 & 8 & 11 & 12 & 22.5 & 0.242535625 & 1.2272727 & 0.3196973 & 1 \\
\hline 2013-15 & 39 & 11 & 7 & 8 & 13 & 27.5 & 0.942809042 & 2.5535714 & 1.4202983 & 2.3 \\
\hline Total & 119 & 24 & 25 & 34 & 36 & 20 & -0.14285714 & 1.0164706 & 0.0438404 & 3.76 \\
\hline
\end{tabular}

Source: Author's calculation

The study has followed two-year sample period for the long run persistence which was termed as perfect test by Goetzmann and Ibbotson (1994). Table 6 reports number of repeat and reversal funds in every two-year interim during the study period. The table depicts that the number of repeat performers is greater than that of reversal in two out of the three interims. Beside that CPR>1 was observed for the total sample period. However the Z- value couldn't 
DOI: 10.14807/ijmp.v11i6.1118

pass the critical value of 1.96, concludes absence of long run performance persistence in Bangladesh mutual funds.

Table 7: Parametric Test

\begin{tabular}{llllll}
\hline \multicolumn{7}{l}{ Dependent Variable: (Ri,t) } & \multicolumn{2}{l}{ Independent Variable: (R i.t-1) } & & \\
\hline Year & Intercept & Slope $(\beta)$ & P-value & T-value & $\mathrm{R}^{2}$ \\
\hline 2012 & -0.009018 & 0.1293522 & $0.014^{* * *}$ & 2.65 & 0.2124 \\
2013 & -0.1498518 & -0.697772 & $0.000^{* * *}$ & -4.08 & 0.3425 \\
2014 & -0.0673976 & 0.6581203 & $0.000^{* * *}$ & 4.89 & 0.3994 \\
2015 & 0.0548217 & 0.4186312 & $0.014^{* * *}$ & 2.56 & 0.1474 \\
\hline
\end{tabular}

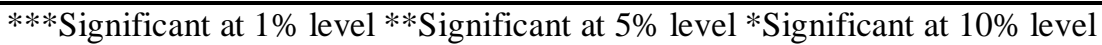

Table 7 depicts positive slopes for most of the sample years. The coefficients for the lagged return are statistically significant at $1 \%$ level. The results of the parametric test are significant to those of the non-parametric test. We conclude that both parametric and nonparametric tests affirm persistence in short run however we failed to find evidence of long term persistent performance in case of Bangladesh mutual funds.

\section{CONCLUSION}

Four factors model in this study reports that past return can predict future return. Although the result of momentum factor is negative yet it is still significant at $1 \%$ level. The results of the study report mutual funds' performance persistence in short run but couldn't find evidence for persistence in long run. Four factor model depicts that fund managers have selective ability to earn positive excess return by investing in low value portfolio or on the basis of prior period winners in Bangladesh market.

Equity mutual fund could perform persistently in short rum confirmed through parametric and non-parametric test. Our short run parametric persistent result is in line to that of (GOETZMANN; IBBOTSON, 1994). Non-parametric test results of non-persistence are also in line with that of Phelps and Detzel (1997). Furthermore, non-parametric test is used for the robustness of short run persistence which reported the same results.

Since mutual funds market is relatively new in Bangladesh, where the first open-end fund is issued in 2010. This small sample size and short period limits the scope of the study and curtails its results from being generalized to other markets. Beside this the study has only addressed the open-ended equity mutual funds in Bangladesh due to difficulty of obtaining data about other types of funds, such as balanced funds and debt funds. Future research could investigate whether changes in management structure can impact mutual funds’ performance persistence in Bangladesh market. 
DOI: 10.14807/ijmp.v11i6.1118

\section{REFERENCES}

ALEXANDER, G.; CICI, G.; GIBSON, S. (2007) Does Motivation Matter When Assessing Trade Performance? An Analysis of Mutual Funds. Review of Financial Studies, v. 20, p. 125-150.

ALLEN, D. E.; TAN, M. L. (1999) A Test of the Persistence in the Performance of UK Managed Funds. Journal of Business Finance and Accounting, v. 26, n. 5-6, p. 559-593.

BAMS, D.; OTTEN, R. (2002) European Mutual Fund Performance. European Financial Management, p. 75-101.

BAUER, R.; OTTEN, R.; RAD, A. T. (2006) New Zealand Mutual Funds: Measuring Performance and Persistence in Performance. Accounting and Finance, v.46, p. 1-17.

BERK, J.; GREEN, R. (2004) Mutual fund flows and performance in rational markets. Journal of Political Economy, p. 1269-1295.

BESSLER, W.; DROBETZ, W.; ZIMMERMANN, H. (2009) Conditional performance evaluation for German Mutual equity funds. The European Journal of Finance, p. 287-316.

BLAKE, D.; TIMMERMANN, A. (1998) Mutual fund performance: evidence from the U.K. European Finance Review, p. 57-77.

BLAKE, D.; LEHMANN, B.; TIMMERMANN, A. (n.d.) Center for Economic policy Research. Retrieved january 18, 2016, from Performance Measurement Using Multi-Asset Portfolio data: http://cepr.org/active/publications/discussion_papers/dp.php?dpno=1618

BOLLEN, N. P.; BUSSE, J. A. (2005) Short-term persistence in mutual fund performance. Review of Financial Studies, v. 18, n. 2, p. 569-597.

BROWN, S. J.; GOETZMANN, W. N. (1995) Performance persistence. Journal of Finance, p. 679-698.

BROWN, S. J.; GOETZMANN, W. N.; IBBOTSON, R.; ROSS, S. (1992) survivorship bias in performance studies. Review of Financial Studies, v. 5, p. 553-580.

CARHART, M. M. (1997) On persistence in mutual fund performance. Journal of Finance, v. 52, n. 1, p. 57-82.

CARLSON, R. (1970) Aggregate Performance of Mutual Funds. The Journal of Financial and Quantitative Analysis, 1948-1967, p. 1-32.

CHEN, J.; HONG, H.; HUANG, M.; KUBIK, J. (2004) Does fund size erode performance? Liquidity, organizational diseconomies, and active money management. American

Economic Review, v. 94, p. 1276-1302.

CHRISTENSEN, M. (2005) Danish Mutual Fund Performance - Selectivity, Market

Timing and Persistence. Aarhus: Working paper, Department of Accounting, Finance and Logistics, Aarhus.

CICCOTELLO, C.; GRANT, C. (1996) Equity fund size and growth: Implications for performance and selection. Financial Services Review, v. 5, p. 1-12.

CLIFFORD, C.; FULKERSON, J.; JORDAN, B.; WALDMAN, S. (2011) Do Investors Care about Risk? Evidence from Mutual Fund Flows.

COMPANY, W. M. (2002) A comparison of active and passive management of unit trusts, p. 1-20: Report for Virgin Money Personal Financial Service. 
CONNOR, G.; KORAJCZYK, R. A. (1991) The attributes, behavior, and performance of U.S. mutual funds. Review of Quantitative Finance and Accounting, v. 1, n. 1, p. 5-26.

CUTHBERTSON, K.; NITZSCHE, D.; O'SULLIVAN, N. (2008) UK mutual fund performance: Skill or luck? Journal of Empirical Finance, v. 15, n. 4, p. 613-634.

DAHLQUIST, M.; ENGSTRÖM, S.; SÖDERLIND, P. (2000) Performance and Characteristics of Swedish Mutual Funds. Journal of Financial and Quantitative Analysis, v. 35, p. 409-423.

DELCOURE, N.; FRENCH, D. W. (2007) Mutual Fund Industry: Case Study of Russian Equity Mutual Funds. Journal of Emerging Markets, p. 23-33.

DUNN, P. C.; THIESEN, R. D. (1983) How consistently do active managers win? Journal of Portfolio Management, p. 47-51.

ELINGA, M.; FAUSTB, R. (2010) The performance of hedge funds and mutual funds in emerging markets. Germany: Institute of Insurance Science, Ulm University,.

ELTON, E. J.; GRUBER, M. J.; BLAKE, C. R. (1996) The persistence of risk-adjusted mutual fund performance. The Journal of Business, v. 69, n. 2, p. 133-157.

ELTON, E. J.; GRUBER, M. J.; RENTZLER, J. (1990) The Performance of Publicly Offered Commodity Funds. Financial Analysts Journal, v. 46, p. 23-30.

ELTON, E. J.; GRUBER, M. J.; DAS, S.; HLAVKA, M. (1993) Efficiency with Costly Information: A Reinterpretation of Evidence from Managed Portfolios. Review of Financial Studies v. 6, n. 1, p. 1-22.

FAMA , E.; FRENCH , K. (1993) Common risk factors in the returns on stocks and bonds. Journal of Financial Economics, n. 33, p. 3-56.

FARNSWORTH, H.; FERSON, W.; JACKSON, D.; TODD, S. (2002) Performance Evaluation with Stochastic Discount Factors. NBER Working Paper, n. 8791.

FERREIRA, M.; MIGUEL, A.; RAMOS, S. (2012) The Determinants of Mutual Fund Performance: A Cross-Country Study. Review of Finance, p. 483-525.

FERSON , W. E.; SCHADT, R. W. (1996) Measuring fund strategy and performance in changing economic conditions. The Journal of Finance, p. 425-461.

FLETCHER, J. (1999) The evaluation of the performance of U.K. American unit trusts. International Review of Economics \& Finance, p. 455-466.

FLETCHER, J.; FORBES , D. (2002) An exploration of the persistence of UK unit trust performance. Journal of Empirical Finance, p. 475-493.

FRIESEN, G.; SAPP, T. (2007) Mutual fund flows and investor returns: An empirical examination of fund investor timing ability. Journal of Banking and Finance, v. 31, n. 9, p. 2796-2816.

GLOSTEN, L.; HARRIS, L. (1988) Estimating the components of the bid-ask spread. Journal of Financial Economics, v. 21, p. 23-142.

GOETZMANN, W.; IBBOTSON, R. (1994) Do winners repeat? Patterns in mutual fund. Journal of Portfolio Management, v. 20, p. 9-18.

GRINBLATT, M.; TITMAN, S. (1989) Portfolio performance evaluation: Old issues and new insights. Review of Financial Studies, p. 2393-422.

GRINBLATT, M.; TITMAN, S. (1993) Performance measurement without benchmarks: An 
DOI: 10.14807/ijmp.v11i6.1118

examination of mutual fund returns. The Journal of Business, v. 66, n. 1, p. 47-68.

GRINBLATT, M.; TITMAN, S. (1989a) Mutual fund performance: An analysis of quarterly portfolio holdings. The Journal of Business, p. 393-416.

GRUBER, M. (1996) Another puzzle: The growth in actively managed mutual funds. Journal of Finance, v. 51, p. 783-807.

HENDRICKS, D.; PATEL, J.; ZECKHAUSER, R. (1993) Hot Hands in Mutual Funds: Short Run Persistence of Relative Performance. Journal of Finance, v. 48, p. 93-130.

HENRIKSSON, R. D.; MERTON, R. C. (1981) On Market Timing and Investment Performance. II. Statistical Procedures for Evaluating Forecasting Skills. Journal of Business, p. 513-533.

HOEPNER, G. A.; HUSSAIN, G. R.; REZEC, M. (2011) Islamic Mutual Funds’ Financial Performance and International Investment Style: Evidence from 20 Countries. The European Journal of Finance, v. 17, n. 9-10, p. 829-850.

HUJJ, J.; POST, T. (2011) On the performance of emerging market equity mutual funds. Emerging Markets Review, p. 238-249.

INDRO, D.; JIANG, C.; HU, M.; LEE, W. (1999) Mutual fund performance: Does fund size matter? Financial Analysts Journal, v. 55, p. 74-87.

IPPOLITO, R. (1989) Efficiency with costly information: A study of mutual fund performance, 1965-1984. The Quarterly Journal of Economics, p. 1-23.

JAIN, P. C.; WU, J. S. (2000) Truth in Mutual Fund Advertising: Evidence on Future Performance and Fund Flows. Journal of Finance, v. 55, n. 2, p. 937-958.

JEGADEESH , N.; CHEN , H.-L.; WERMERS , R. (2000) The Value of Active Mutual Fund Management: An Examination of the Stockholdings and Trades of Fund Managers. p. 343-368.

JEGADEESH, N.; TITMAN, S. (1993) Returns to buying winners and selling losers: Implications for stock market efficiency. Journal of Finance, v. 48, p. 65-91.

JENSEN, M. (1968) The performance of mutual funds in the period 1945-1964 Journal. Journal of Finance, v. 23, p. 389-416.

KAHN, R. N.; RUDD, A. (1995) Does Historical Performance Predict Future Performance? Financial Analysts Journal, v. 51, n. 6, p. 43-52.

KRITZMAN, M. (1983) Can Bond Manager Perform Consistently? Journal of Portfolio Management, p. 54-56.

LOU, D. (2012) A flow-based explanation for return predictability. Review of Financial Studies, p. 3457-3489.

LU, Z. (1999) Is money smart? a study of mutual fund investors' fund selection ability. The Journal of Finance, v. 54, n. 3, p. 901-933.

LUNDE, A.; TIMMERMANN, A.; BLAKE, D. (1998) The hazards of mutual fund underperformance: A Cox regression analysis. Journal of Empirical Finance, p. 1-39.

MAGINN, J.; TUTTLE, D. (1990) Managing investment portfolios: A dynamic Process, 2nd ed. Boston, MA.: Warren, Gorham \& Lamont.

MAINS, N. (1977) Risk, the Pricing of Capital Assets, and the Evaluation of Investment Portfolios: Comment. The Journal of Business, p. 381-384. 
MALKIEL, B. (1995) Returns from Investing in Equity Mutual Funds 1971 to 1991. Journal of Finance, v. 50, p. 549-72.

PHELPS , S.; DETZEL, L. (1997) The non persistence of mutual fund performance.

Quarterly Journal of Business and Economics, v. 36, p. 55-69.

QUIGLEY, G.; SINQUEFIELD, R. A. (2000) Performance of U.K. equity unit trusts. Journal of Asset Management, p. 72-92.

RHODES, M. (2000) Past Imperfect? The performance of UK equity managed funds. FSA Occasional Paper Series, v. 9, p. 1-58.

SCHWAGER, J. (2012) Market Sense and Nonsense: How the Markets Really Work (and How They Don't) Hoboken,New jersey: John Wiley \& Sons Inc; 1 edition.

SHARPE, W. (1966) Mutual fund performance. Journal of Business, v. 39, p. 119-138.

SIRRI, E.; TUFANO, P. (1998) Costly Search and Mutual Fund Flows. Journal of Finance, V. 53, p. 1589-1622.

SOUZA, A. (2015) Fund raw return and future performance. Journal of Finance.

SPENCER, P. D. (2000) The Structure and Regulation of Financial Markets. Oxford University Press.

T, W.; T, G.; T, W. (2002) Performance peristance in uk equity funds- A Literature review. London: Association of Unit Trust and Investment Funds.

TREYNOR, J. L. (1966) How to rate management investment funds. Harvard Business Review, p. 63-75.

TREYNOR, J. L.; MAZUY, K. K. (1966) Can mutual funds outguess the market? . Harvard Business Review, p. 131-136.

WERMER, R. (2000) Mutual fund performance: An empirical decomposition into stockpicking talent, style, transactions costs and expenses. Journal of Finance, p. 16551695. 